\title{
The Reactivity and Ultrastructure of Conjunctival Microaneurysms in Diabetes*,**
}

\author{
Bernard I. Chazan, Toichiro Kuwabara, Marios C. Balodimos, and Wirliam P. Beetham
}

The Elliott P. Joslin Research Laboratory, Department of Medicine, Harvard Medical School, the Joslin Clinic, the New England Deaconess Hospital, the Diabetes Foundation, Inc., and the Howe Laboratory of Ophthalmic Pathology, Massachusetts Eye and Ear Infirmary, Boston, Massachusetts

Received: February 3, 1969

Summary. The response of conjunctival vascular dilatations to topical epinephrine was tested in 25 subjects. Trregular venular dilatations disappeared, venular microaneurysms underwent partial contraction, while capillary microaneurysms did not contract following application of epinephrine. Biopsy specimens of the conjunctiva were examined by light and electron microscopy in four diabetic patients in whom microaneurysms had been demonstrated by biomicroscopy. Marked thickening of the basement membrane and enlargement of the endothelial cytoplasm were noted in the dilated capillaries. Pericytes were normal in number and appearance. Conjunctival capillary dilatations in three nondiabetics failed to show these changes. A milder degree of basement membrane thickening was observed in a younger diabetic. The finding of conjunctival capillary microaneurysms in a diabetic would thus appear to indicate the presence of microangiopathy.

La réactivité et l'ultrastructure des microanévrysmes conjonctivaux dans le diabète

Résumé. La réponse des dilatations vasoulaires conjonctivales à l'application locale d'adrénaline a été testée chez 25 sujets. Les dilatations veinulaires irrégulières disparaissaient, les microanévrysmes veinulaires subissaient une contraction partielle, tandis que les microanévrysmes capillaires ne se contractaient pas après application d'adrénaline. Des spécimens de biopsie de la conjonctive ont été examinés au microscope à lumière et au microscope électronique chez quatre sujets diabétiques, chez lesquels les microanévrysmes avaient été mis en évidence par biomicroscopie. On a noté un épaississement marqué de la membrane basale et un agrandissement du cytoplasme endothélial dans les capillaires dilatés. Les péricytes étaient normaux en nombre et en apparence. Chez trois non-diabétiques les dilatations capillaires conjonctivales n'ont pas subi ces modifications. On a observé un degré plus faible d'épaississement de la membrane basale chez un diabétique plus jeune. La découverte de microanévrysmes capillaires conjonctivaux chez un diabétique semblerait done indiquer la présence de microangiopathie.

Reaktionen und Ultrastruktur von Bindehaut-Mikro. aneurysmen bei Diabetes

Zusammenfassung. Das Ansprechen von Bindehautgefäß-Aneurysmen auf lokale Adrenalinapplikation wurde boi $25 \mathrm{Vp}$. überprüft. Darunter verschwanden unregelmäßige venöse Erweiterungen und die venösen Mikroaneurysmen kontrahierten sich teilweise, während sich die kapillären Mikroaneurysmen unter Adrenalin nicht verkleinerten. Biopsiepräparate aus der Bindehaut von 4 Diabetikern, bei denen sich durch Biomikroskopie Mikroaneurysmen hatten nachweisen lassen, wurden licht- und elektronenmikroskopisch untersucht. In den erweiterten Kapillaren fielen dabei eine deutliche Verdickung der Basalmembran und eine Vermehrung des endothelialen Cytoplasma auf. Die Pericyten erschienen nach Zahl und Aussehen normal. Erweiterungen von Bindehautkapillaren bei 3 Nichtdiabetikern zeigten diese Veränderungen nicht. Bei einem jüngeren Diabetiker lie $\beta$ sich eine weniger ausgeprägte Verdickung der Basalmembran beobachten. Der Nachweis von Mikroaneurysmen in den Bindehautkapillaren eines Diabetikers spricht also für das Vorliegen einer Mikroangiopathie.

Key-words: Microaneurysms (conjunctival), Ultrastructure, Epinephrine.
Localized venular dilatations, variously referred to as "micropools" or "microaneurysms", have been described in the bulbar conjunctival vasculature by many observers. They can readily be visualized by the use of the standard corneal slit-lamp microscope or even by using an ophthalmoscope with $a+20$ lens. In contrast to retinal microaneurysms, however, conjunctival micropools have been found not only in $40 \%$ of diabetic patients, but also in $35 \%$ of hypertensives, and in $30 \%$ of patients with arteriosclerosis [7], and these

* Presented in part at the 28th annual Meeting of the American Diabetes Association in San Francisco, on June 16,1968

** This investigation was conducted under a Fight for Sight Postdoctoral Research Fellowship of the National Council to Combat Blindness, Inc., New York, New York (Dr. ChazAN), and supported by grants from the U.S. Public Health Service (NB 02698 and AM - 04146), the Massachusetts Lions' Eye Research Fund, and the John A. Hartford Foundation, Ine. same micropools occur in $42 \%$ of mothers of big babies [2].

In apparently normal individuals a frequency of $14 \%$ has been reported [7]. In these studies, temporal and nasal aspects of both conjunctivae were examined by biomicroscopy. Ditzed [8] who examined only the lateral parts of both conjunctivae and considered only globular microaneurysms, found a frequency of only $4 \%$ in juvenile diabetics, which was the same as in the nondiabetic control group. True microaneurysms have been demonstrated in the conjunctiva of diabetics by histologic means $[5,10]$, but the electron microscope appearance has not been described.

In this study, we have used topical epinephrine in an attempt to confirm the clinical distinction between irregular venular dilatations and the microaneurysms, and have demonstrated the presence of true microaneurysms in the conjunctivae of four diabetic patients by electron microscopy. 


\section{Material and Methods}

Conjunctival biomicroscopy was carried out by a modification of the technique described by Ditrzes and ST. Clatr [9]. The modified technique allows for rapid screening and instant photography of all fields of both nasal and temporal aspects of the conjunctivae. An electronic flash tube (EG and $G$ ), built into a microscope illuminator with a focusing lamp, supplied the light for examining and the flash for photography. A green filter was fitted to the stroboscopic lamp for
Venutar microaneurysms: Sharply localized saccular or fusiform swellings whose diameter is at least three times that of the venules.

Capillary microaneurysms: Globular dilatations of the venular end of the capillary. Only dilatations which persisted during five minutes of screening were considered as microaneurysms.

Excised conjunctival tissues were fixed in four percent glutaraldehyde in $\mathrm{pH} 7.2$ phosphate buffer for twenty minutes, and postfixed in one percent osmium

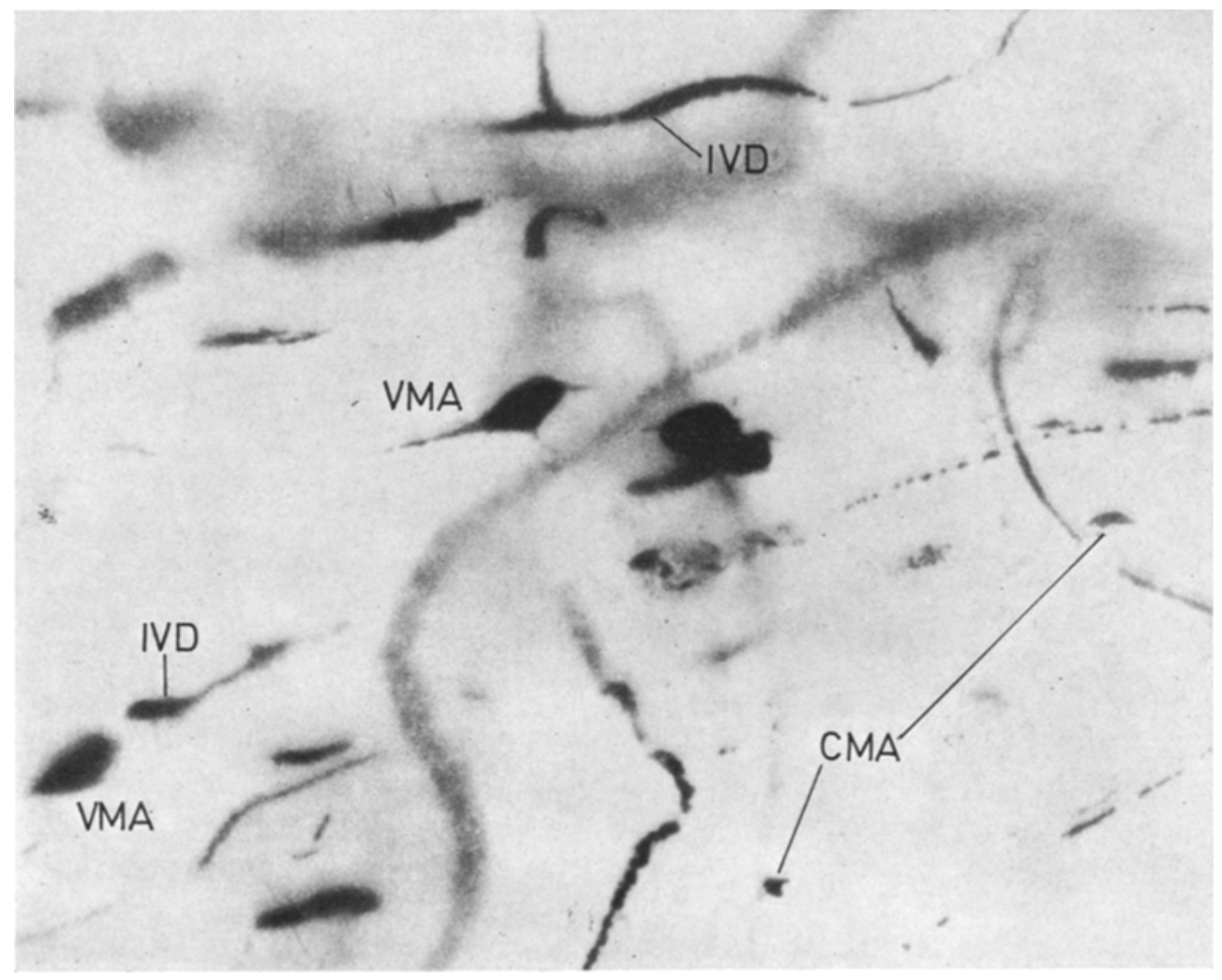

Fig. 1. Irregular venular dilatations (IVD), venular microaneurysms (VMA) and capillary microaneurysms (CMA) in the conjunctiva of a 39 year-old woman with proliferative retinopathy. $\times 45$

sharper definition of blood flow during prolonged observation. The stroboscopic lamp was attached to the microscope stand by a movable horizontal arm. A $35 \mathrm{~mm}$ Leica $3 \mathrm{~F}$ camera was used with a Visablex housing, 5 times field magnifier, bellows, an $11 \mathrm{~mm}$ extension tube, and a Zeiss $40 \mathrm{~mm}$ lens. This allowed magnification of the order of $25 \times$ to $45 \times$ for viewing, $5 \times$ to $9 \times$ on the negatives, and $50 \times$ to $90 \times$ on the prints.

The following definitions were used throughout the study: [3] (Fig. 1).

Irregular venular dilatations: Elongated areas of venular dilatation whose diameter is no more than twice that of the venules. tetroxide in the same buffer solution for one and a half hours. During the initial fixation, the areas containing pathological blood vessels were carefully dissected out for further processing. The tissues were embedded in epoxy resin (Epon), sectioned by an ultramicrotome, and doubly stained with uranyl acetate and lead citrate. A Jeolco (Medford) electron microscope was used.

In the course of routine conjunctival examinations on 25 normals, 25 prediabetic and 30 diabetic subjects, we found 25 patients with persistent vascular dilatations. These were re-examined three minutes after the local instillation into the conjunctiva of one percent epinephrine eye drops. Photographs were taken in every case before and after instillation, and the degree 
of constriction induced by epinephrine was determined. Seventeen of the patients were diabetic, three were the offspring of two diabetic parents ("prediabetic"), and five were normal.

In the second part of this study we screened patients with diabetes referred to one of us (W.P.B.) for cataract operation. Four of the patients with capillary and/or venular micropools had their lesions photographed. At operation a biopsy specimen was taken from the area of the conjunctiva in which microaneurysms had been found, and the material examined by light and electron microscopy (EM). These four cases are described as follows.

Case 1. (J.C. 16050) was a 48 year-old woman with known diabetes for 34 years (onset at age 14). She had absent pedal pulses and a tendency to hypertension $(160 / 95)$. There was no proteinuria and BUN was $14 \mathrm{mg} /$ $100 \mathrm{ml}$. The retinal vessels had appeared normal in 1960 , but had not been satisfactorily visualized since then because of cataracts.

Case 2. (J.C. 60772) was a 67 year-old woman with known diabetes for 23 years (onset at age 44). She had normal pedal pulses, normal blood pressure (140/70), no proteinuria and a normal BUN (17 $\mathrm{mg} / 100 \mathrm{ml}$.). She had blot haemorrhage and microaneurysms in the retina; early neovascularization had appeared in recent months. Arcus senilis was prominent, and she had had bypercholesterolaemia $(278-296 \mathrm{mg} / 100 \mathrm{ml})$ for the last three years. In both of these patients capillary and venular microaneurysms were found in the nasal region of the left eye, in the perilimbal zone.

Case 3. (J.C. 73508) was an 86 year-old man with diabetes for 15 years (onset at age 71). Pedal pulses and blood pressure $(150 / 80)$ were normal. Proteinuria was intermittently present, but BUN was never more than $20 \mathrm{mg}$ $100 \mathrm{ml}$ and the blood creatinine was $1.5 \mathrm{mg} / \mathrm{ml}$. He had suffered in the past from an anteroseptal myocardial infarction. The retina was not visualized. Saccular and fusiform venular micropools and capillary microaneurysms were found in the temporal part of the left bulbar conjunctiva.

Case 4. (J.C. 71588) was a 74 year-old-man with diabetes for at least 9 years (onset at age 65). This was the only patient who was not insulin-dependent, and was treated with chlorpropamide. He suffered from angina pectoris. Examination was normal apart from absent tibialis posterior pulsations. He was normotensive. The retina was not visible. He had hypercholesterolaemia $(299 \mathrm{mg} / 100 \mathrm{ml})$, but no proteinuria or azotaemia. Venular and capillary microaneurysms were found in the nasal part of the left bulbar conjunctiva.

In addition to the above patients who were examined prospectively, conjunctival microaneurysms were found by chance in biopsy material submitted at operation, in a further four patients.

Case 5. (MEEI 136-76-99). This 11 year old girl, an insulin-dependent diabetic since the age of two and a half years, had suffered at the age of six from StevensJohnson syndrome. She was admitted for treatment of the resulting scleral scarring.

Physical examination revealed an asthenic girl with normal peripheral pulses, blood pressure 140/70, and normal retinal vessels. On admission the fasting blood glucose was 445 and blood cholesterol $255 \mathrm{mg} / 100 \mathrm{ml}$. There was 4 plus glycosuria and a trace of acetone but no albuminuria. BUN was $18 \mathrm{mg} / 100 \mathrm{ml}$.

At operation, for scleral moulding and fitting for corneal lenses, chronic conjunctivitis was noted and biopsy material taken from the nasal aspect of the conjunctiva of the left eye near the limbus.
Case 6. (MEET 142-79-74). This was a 49 year-old woman whose right eye was enucleated during operation for adenocarcinoma of the maxilla. Peripheral pulses, retinal vessels, blood pressure (140/80) and an electrocardiogram were normal, as were the fasting and two hour postprandial blood glucose levels. BUN $15 \mathrm{mg} / 100 \mathrm{ml}$, Blood cholesterol $245 \mathrm{mg} / 100 \mathrm{ml}$.

Case 7. (MEEI 172-79-76). A 50 year-old woman was admitted for recurrent ecchymoses in the upper eyelids. She was hypertensive $(200 / 110)$, peripheral circulation was normal and repeated post-prandial blood glucose levels were normal. BUN was $20 \mathrm{mg} / 100 \mathrm{ml}$. There was $50 \mathrm{mg} / 100 \mathrm{ml}$ protein in the urine.

Case 8. (MEEI 101-88-40). This 51 year-old man underwent operation for excision of a simple conjunctival cyst. As with the preceding two patients, blood glucose levels were normal. There was no clinical evidence of atherosclerosis a part from slight retinal venular tortuosity. Blood pressure was $140 / 80$, there was no proteinuria, BUN $10 \mathrm{mg} / 100 \mathrm{ml}$, blood cholesterol $230 \mathrm{mg} / 100 \mathrm{ml}$.

\section{Results}

In the first part of the study, 38 vascular dilatations were found in the 25 subjects tested, whose ages ranged from 25 to 60 ( $39 \pm 2.8 \mathrm{SEM}$ ). There were six irregular venular dilatations, 15 venular microaneurysms, and 17 capillary microaneurysms. The response of each of these lesions is considered separately, independent of whether the patient was normal, prediabetic or diabetic, as there is no clinical method of differentiating between "diabetic" and "non-diabetic" microaneurysms in the conjunctiva. The vascular dilatations were most commonly found in the nasal perilimbar zone.

Table 1. The Effect of Topical Epinephrine 1\% on Vascular Dilatations

\begin{tabular}{|c|c|c|c|c|}
\hline & Total & $\begin{array}{l}\text { Nor- } \\
\text { mal }\end{array}$ & $\begin{array}{l}\text { Predia- } \\
\text { betic }\end{array}$ & Diabetic \\
\hline No. of patients & 25 & 5 & 3 & 17 \\
\hline $\begin{array}{l}\text { No. of Vascular } \\
\text { dilatations }\end{array}$ & 38 & 5 & 5 & 28 \\
\hline $\begin{array}{l}\text { Venular dilatations } \\
\text { No. constricted } \\
\end{array}$ & $\begin{array}{l}6 \\
6^{++} \\
\end{array}$ & $\begin{array}{l}1 \\
1^{++} \\
\end{array}$ & $\begin{array}{l}2 \\
2++ \\
\end{array}$ & $\begin{array}{l}3 \\
3^{++} \\
\end{array}$ \\
\hline $\begin{array}{l}\text { Venular MAsb } \\
\text { No. constricted }\end{array}$ & $\begin{array}{c}15 \\
9+ \\
\end{array}$ & $\begin{array}{l}2 \\
1^{+} \\
\end{array}$ & $\begin{array}{l}1 \\
1+ \\
\end{array}$ & $\begin{array}{c}12 \\
7^{+} \\
\end{array}$ \\
\hline $\begin{array}{l}\text { Capillary MAs } \\
\text { No. constricted }\end{array}$ & $\begin{array}{c}17 \\
2^{+}\end{array}$ & $\begin{array}{l}2 \\
0\end{array}$ & $\begin{array}{l}2 \\
0\end{array}$ & $\stackrel{13}{2^{+}}$ \\
\hline
\end{tabular}

a Constriction: ${ }^{+}=$partial, ${ }^{++}=$complete.

b $\mathrm{MA}=$ microaneurysm

The effect of epinephrine is detailed in the table. Epinephrine constricted all the smaller conjunctival vessels - arterioles, capillaries and venules - and rendered the whole vascular field ischaemic. In all cases, irregular venular dilatations disappeared after epinephrine administration. An example of this response, in a 32 yearold, normal subject (with four normal glucose tolerance tests), is seen in Fig. 2. Nine of the fifteen venular microaneurysms were partially constricted after the instillation of epinephrine, at most to half their initial size. Of the 17 capillary microaneurysms, 15 showed no 
response to epinephrine and two a slight degree of constriction. Fig. 3 shows an unusually large dilatation, which, after exposure to epinephrine, resolved itself into separate venular and capillary micropools. The patient was a 48 year-old diabetic of 18 years duration.

Microaneurysms were demonstrated in the biopsy specimens from all four of the diabetic patients so examined. Histological examination showed them to
The normal blood capillary in the bulbar conjunctiva of the human has an outer diameter of about 15 to 25 micra. Electron microscopic examination shows that the lining endothelial cytoplasm is of moderate thickness and is not fenestrated. The microorganelles are no different from those of other capillary endothelia. The outside of the endothelial cell layer is covered with a thin, unbroken layer of basement membrane.
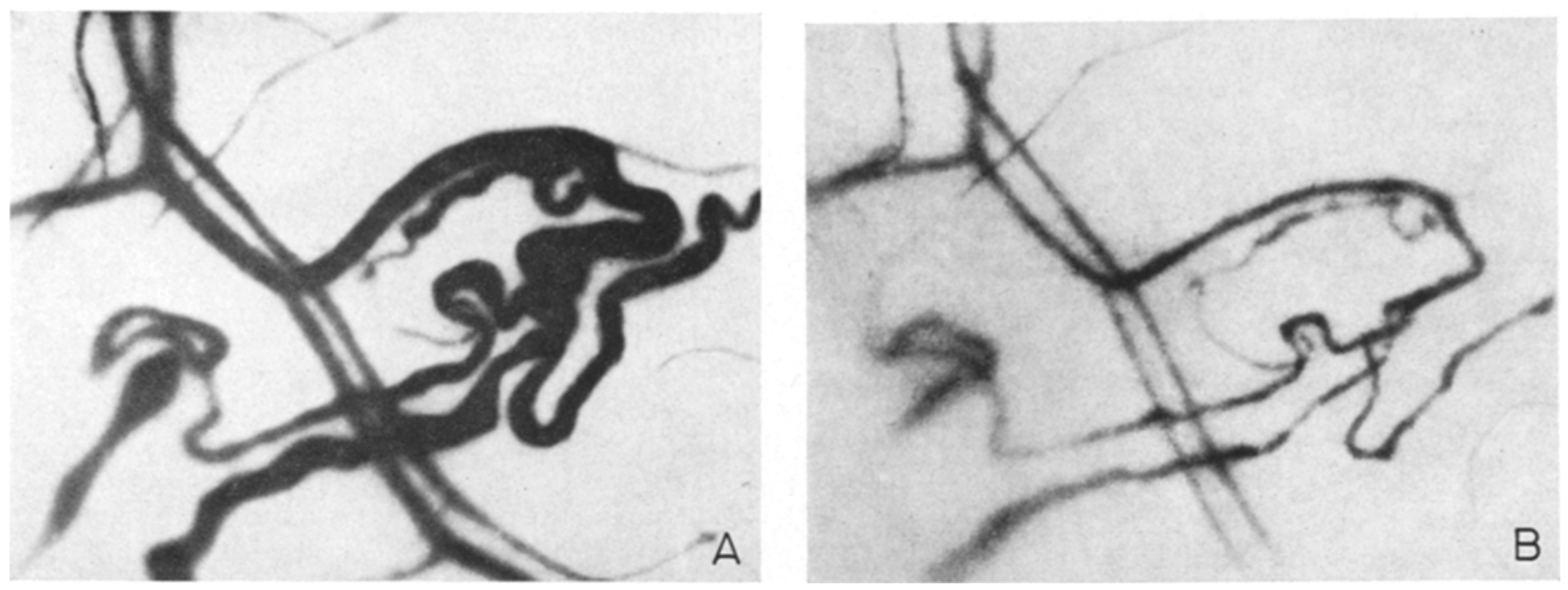

Fig. 2. Irregular venular dilatations before $(A)$ and after $(B)$ topical epinephrine $1 \% \cdot \times 45$
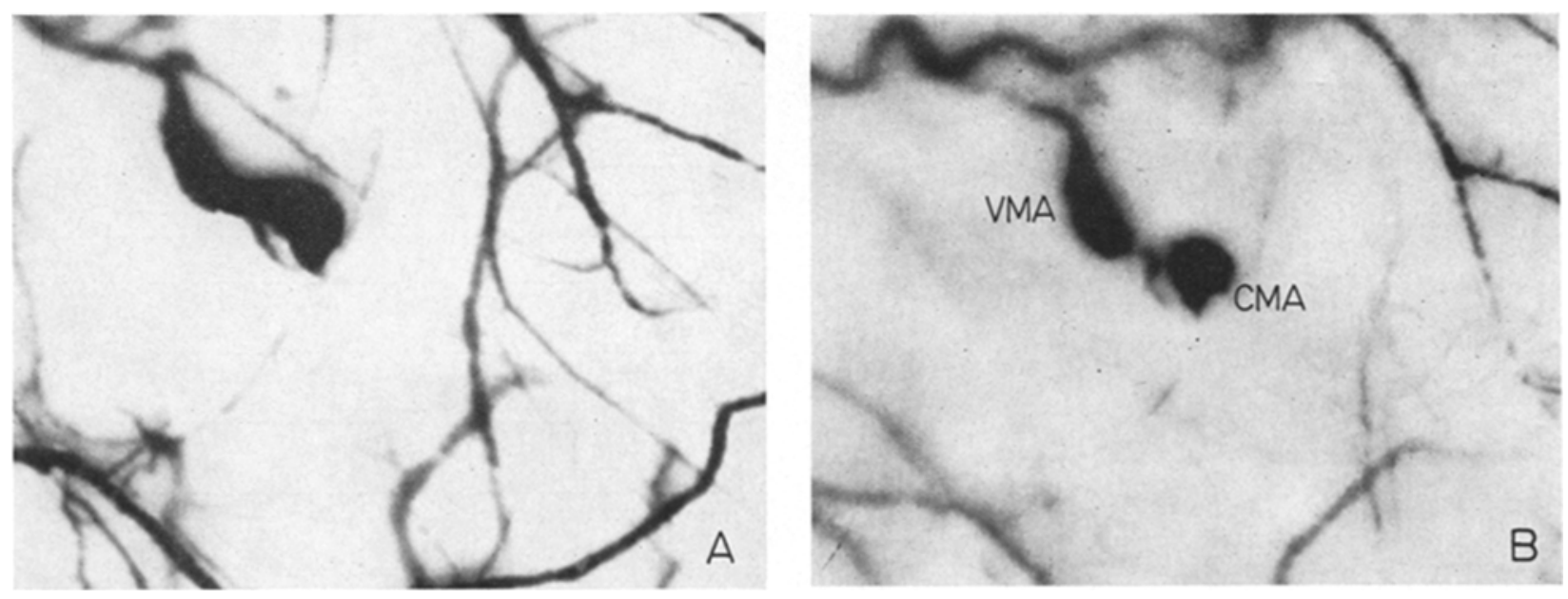

Fig. 3. Unusually large vascular dilatation in a diabetic patient (A). Epinephrine application (B) revealed capillary (CMA) and venular microaneurysms (VMA). $\times 45$

consist of dilated, tortuous vessels which formed clusters in the immediate subepithelial zone (Fig. 4.) These pathological vessels were easily distinguished from the normal large blood vessels. The latter were usually found in the deeper zone, and showed the paired arrangement of arteries and veins. The connective tissue in this area showed moderate thickening, but no inflammatory cells were seen in the subepithelial tissue or in the epithelium. Capillaries of normal size were frequently seen in the vicinity.
Fine structural findings of the dilated capillaries of all four cases were quite similar. The endothelial cells were markedly thickened. Their cytoplasm contained numerous vacuoles and inclusion bodies in various sizes and densities. Some endothelial cells were occupied by massive fibril materials (Fig. 5). There were many infoldings and cytoplasmic protrusions in the inner surface. Thickening of the basement membrane was striking in these pathologic vessels. Many vessels were encased in several layers of proliferated basement mem- 


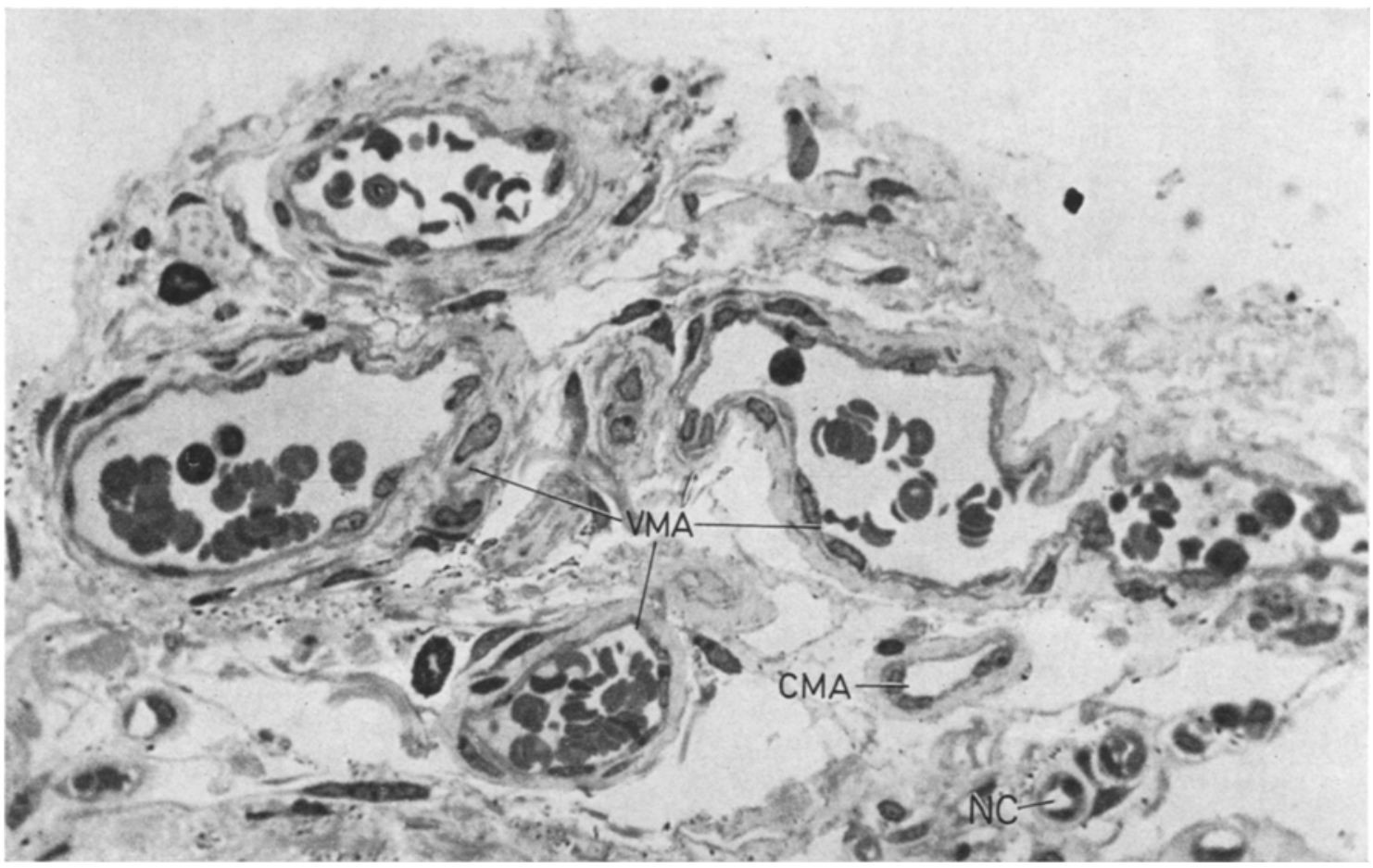

Fig. 4. Photomicrograph of conjunctival biopsy specimen from diabetic patient. no. 1. Note thickened wall of the dilated segment of the capillary (CMA) and venule (VMA) in contrast to the nest of normal undilated capillaries $(\mathrm{NC})$

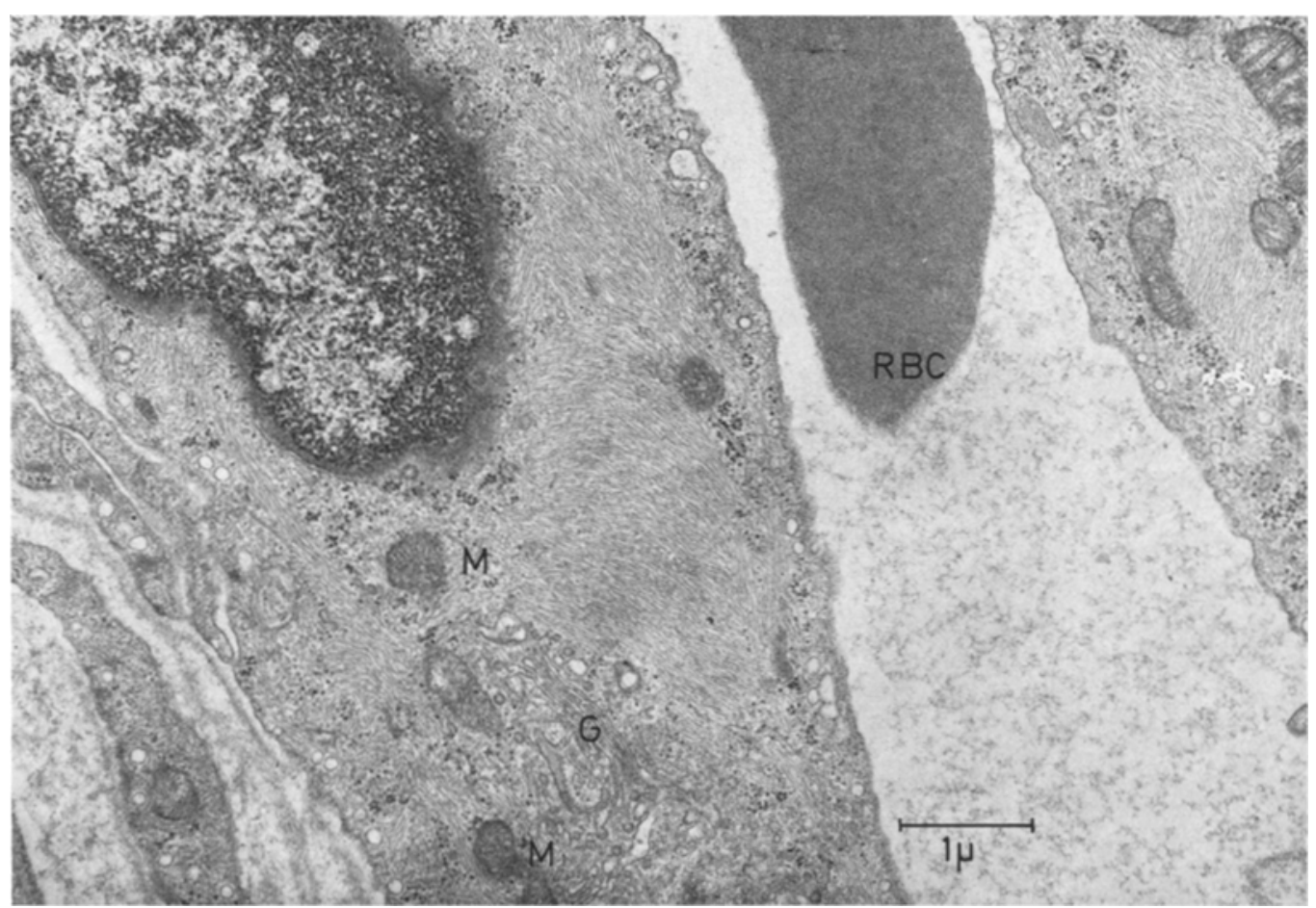

Fig. 5. Electron micrograph of capillary microaneurysm in diabetic patient no. 2 showing fibrillary changes in the endothelial cell cytoplasm. Normal mitochondria (M), Golgi apparatus (G), and red blood corpuscle $(\mathrm{RBC})$ 


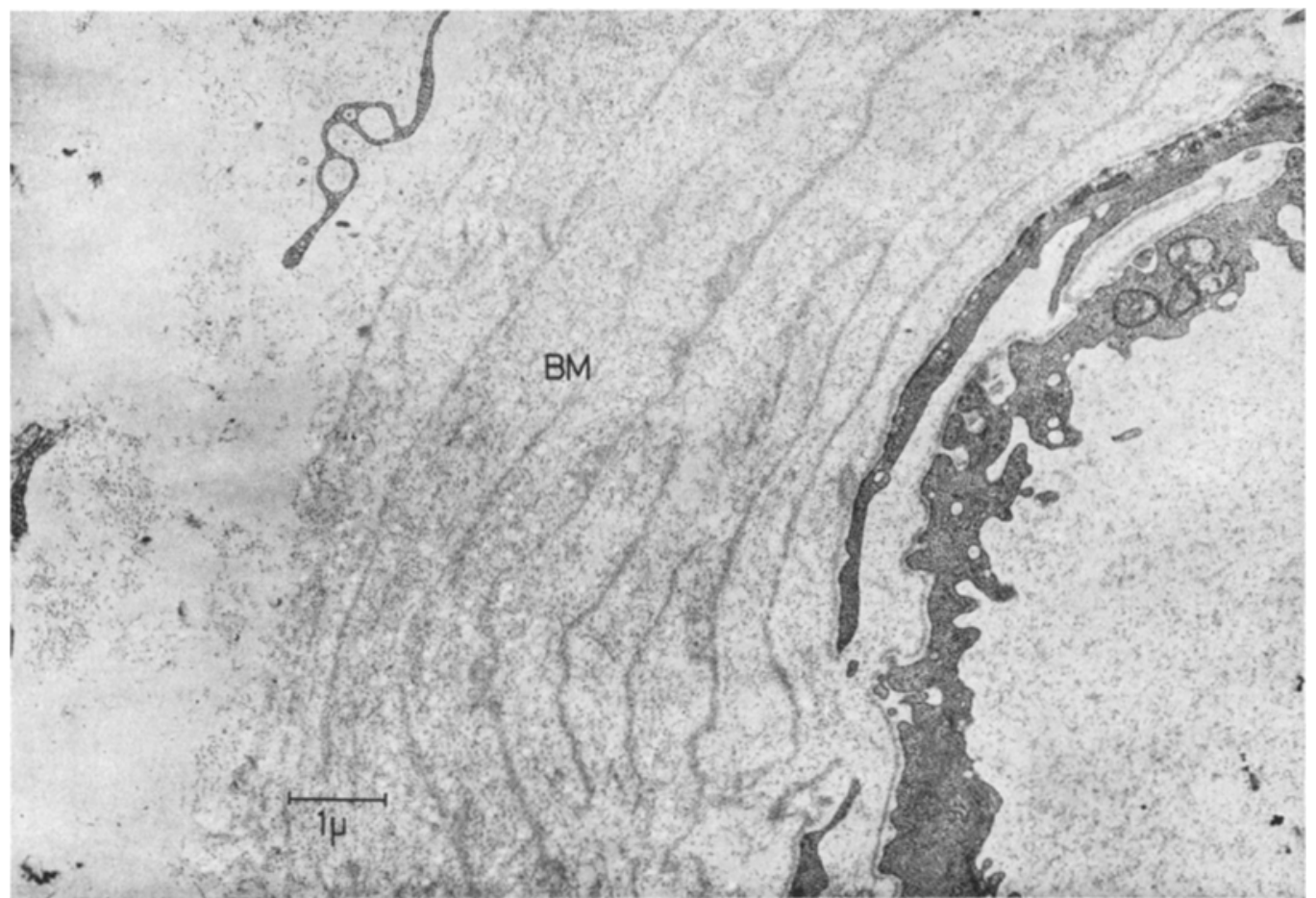

Fig. 6. EM of capillary microaneurysm in diabetic patient no. 1. Note lamellar thickening of the basement membrane (BM)

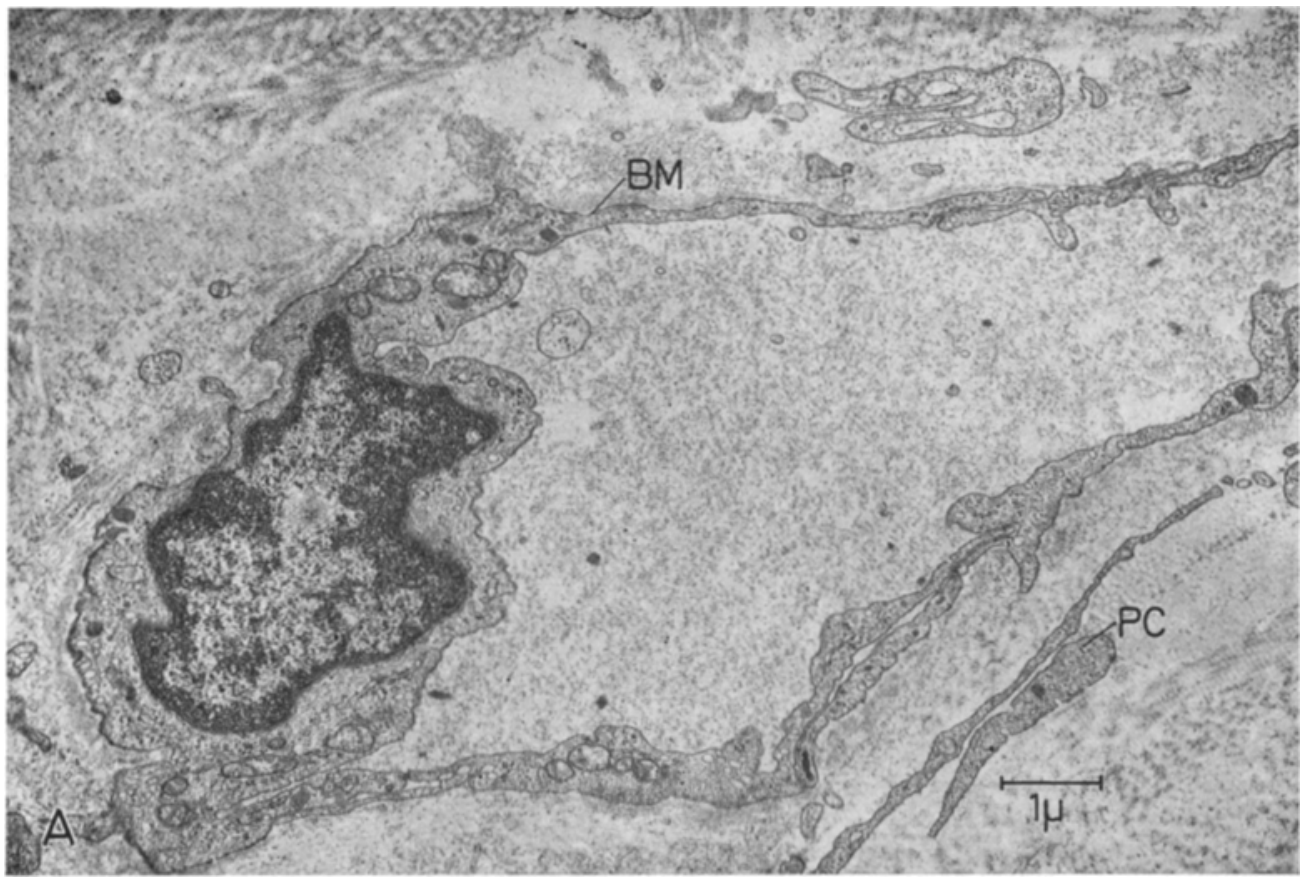

Fig. 7. Ultrastructure of capillary microaneurysms in (A) a 51 year old non-diabetic (no. 8)

brane, which formed an onionskin arrangement (Fig. 6). Some vessels were surrounded by an extremely thick and compact basement membrane (Fig. $7 \mathrm{c}$ ). It measured one-half micron or more in thickness. Pericytes were often found buried in the thickened membrane.
By contrast, the non-dilated capillaries appeared normal.

Some degree of basement membrane thickening was found in the young patient with diabetes (Fig. 7b), but this did not approach the extreme changes in older 


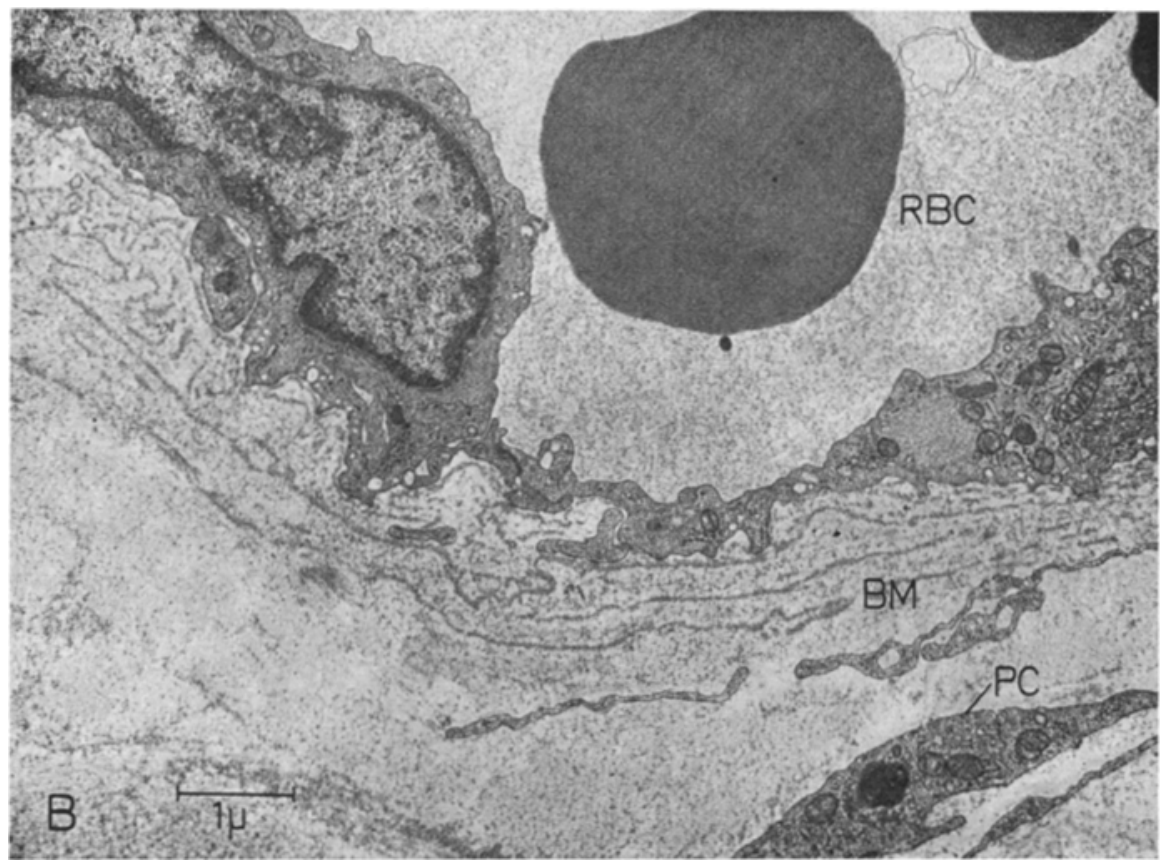

(B) an 11 year old diabetic of 9 years' duration (no. 5)

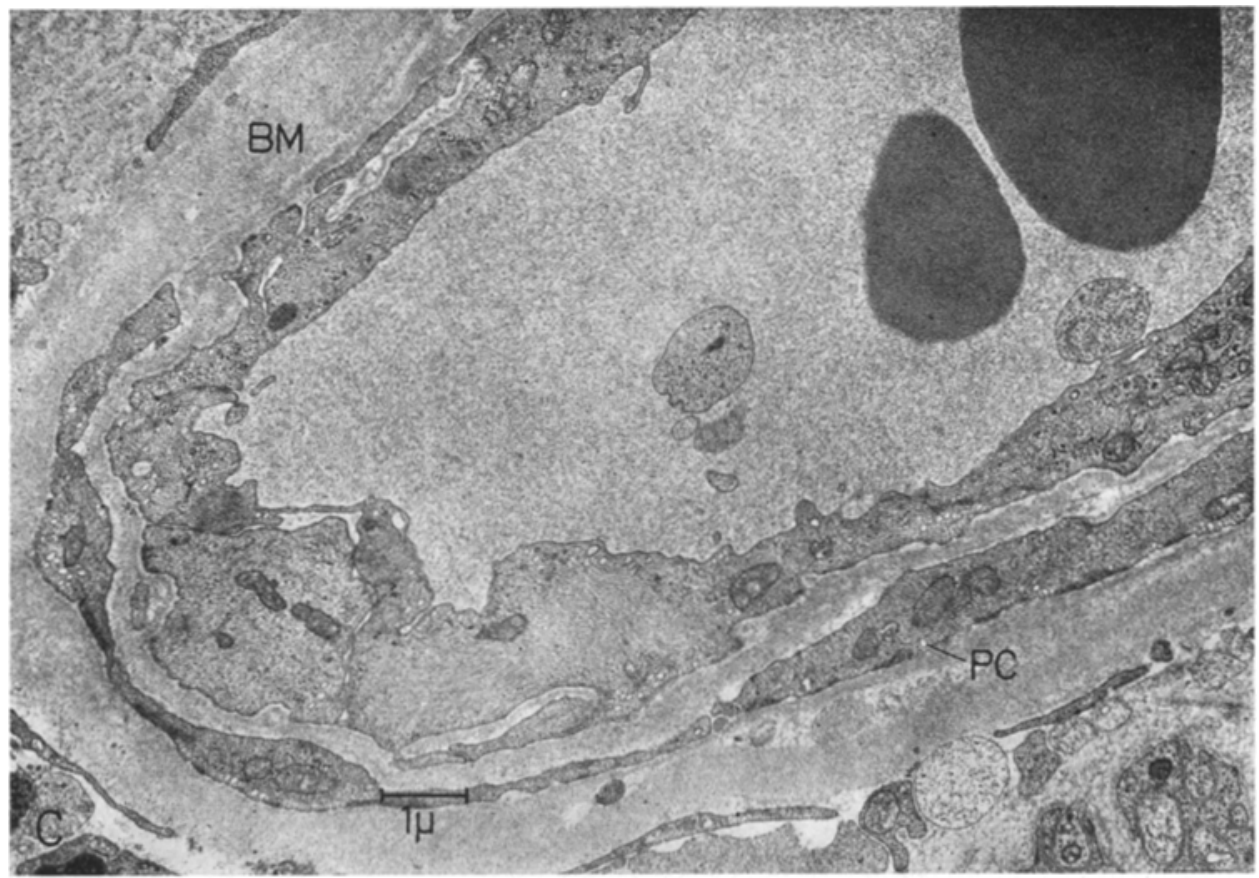

(C) an 86 year old diabetic of $15^{+}$years' duration (no. 3) Note increasing thickness of basement membrane (BM) from (A) to (C) and pericytes (PC)

diabetics, and could be attributed to chronic conjunctivitis. None of the other patients had conjunctivitis.

The patients without diabetes or generalized vascular disease, although older, had a delicate basement membrane (Fig. 7 a).

\section{Discussion}

Epinephrine drops have previously been used to study the vascular reactivity of the conjunctiva [11]. Davis and LANDAU [6], using two drops of a 1:200000 dilution of epinephrine, demonstrated conjunctival 
vessel thinning in close relatives of hypertensive patients. We had previously noted that generalized conjunctival vascular constriction followed instillation of atropine and phenylephrine drops for pupillary dilatation. The apparent sparing of microaneurysms, however, prompted this study of the effects of epinephrine alone in small vessel dilatations. The standard $1 \%$ eye drops were used in order to guarantee diffuse capillary thinning in all cases. The preliminary results of epinephrine instillation suggest that capillary microaneurysms are virtually unaffected by topical epinephrine even when the whole vascular field is rendered ischaemic. On the other hand, irregular venular dilatations can be made to disappear temporarily. It appears not unlikely that these common venular dilatations are a reversible stage in the development of venular microaneurysms. We have found these irregular venular dilatations to be twice as common as microaneurysms in 50 normal controls (11 and 6 respectively), (unpublished observations), whereas in advanced diabetes we found microaneurysms accompanied by venular dilatations in $50 \%$ of cases.

It would be interesting to know whether thickened basement membrane is a factor in prevention of full contraction by the conjunctival microaneurysm in the older diabetic patient. This possibility is especially intriguing in view of the persistence of the pericytes in conjunctival, as opposed to retinal, microaneurysms [4].

The increased frequency of microaneurysms in the elderly [13] has been ascribed to diabetes, arteriosclerosis, and hypertension.

The first four patients were admittedly older and had more severe atherosclerosis. However, atherosclerosis does not typically affect the capillary basement membrane, and the thickest basement membrane was encountered in the biopsy from the youngest patient (Case 1. -48 years old). Moreover, the 11 year-old girl with nine years' diabetes showed considerable changes in the basement membrane of the conjunctival microaneurysms, which were absent in the 51 year-old non-diabetic.

It is apparent that the endothelial cells in certain conjunctival vessels are abnormal in diabetes. Although the precise pathogenic nature of the change is not shown clearly in this study, the capillaries in which endothelial cells show pathologic findings are markedly dilated. The thickening and lamellar formation of the basement membrane may appear to be secondary to the cellular change of the capillary, but this is difficult to prove.

The light microscope findings in this study confirm those described by Funahasht and Fink [10] in nine diabetic patients. Other histological $[1,14]$ and electron microscopic [12] studies have shown some degree of basement membrane thickening and even diffuse endothelial cell hyperplasia [14] in the conjunctival vessels of diabetics, but the ultrastructure of microaneurysms has not previously been reported.

Acknowledgments. The senior author is indebted to Professor E. DAvis for experience gained in his laboratory in Jerusalem, Israel. The authors wish to express their appreciation to Mr. Donald C. Withee and Miss Sheilla H. MeEk for photography, to Miss Theresa M. SMIth, R.N., and to Mrs. MARY C. Goutsos for technical assistance.

\section{References}

1. Agarwal, L.P., H.N. ChHabra, and R. Batta: Conjunctival vessels in diabetes mellitus. Orient. Arch. Ophthal. 4, 141-147 (1966).

2. Chazan B.I., Y. Eliashar, A. Brzezinski, and E. DAvis: Small blood vessel changes and the chylomicron count in mothers of big babies. Diabetes 13, $291-296$ (1964).

3. - and M.C. BaLodimos: Conjunctival vascular lesions: Classification and clinical significance, with special reference to diabetes. Acta Diabet. Lat. In press.

4. Cogan, D.G., D. Toussaint, and T. Kuwabara: Retinal vascular patterns. IV. Diabetic retinopathy. A.M.A. Arch. Ophthal. 66, 366-378 (1961).

5. Davis, E., and J. Landau: Clinical Capillary Microscopy, p. 52. Springfield, U.S.A.: Charles C. Thomas 1966.

6. - - The influence of adrenaline on the small blood vessels in normotension and hypertension. Bibl. anat. 9, 1-6 (1966).

7. - - , and B.I. Chazan: The incidence and significance of conjunctival micropools. Bibl. anat. 7, 543$546(1965)$.

8. Ditzmi, J.: Morphological and hemodynamic changes in the smaller blood vessels in diabetes mellitus. New Engl. J. Med. 250, 587-594 (1954).

9. -, and R.W. Str. CLAIR: Clinical method of photographing the smaller blood vessels and the circulating blood in the bulbar conjunctiva of human subjects. Circulation 10, 277-281 (1954).

10. Funahasmo, T., and A.I. FrnK: The pathology of bulbar conjunetiva in diabetes mellitus. I. Microaneurysms. Amer. J. Ophthal. 55, 504-510 (1963).

11. KaviII, S.: Essential hypertension. Clinical and microcirculatory observations in affected families. Hebrew University Hadassah Medical School: M.D. Thesis 1965.

12. Lentr, G., C. Toselli, F. Strigu, A. Serra, and A. Pellegrini : Rilievi di microscopia ottica ed elettronica sui capillari congiuntivali in corso di malattia diabetica. Acta Diabet. Lat. 3, $340-350$ (1966).

13. MoCuluoch, C., and T.J. Pashby: The significance of conjunctival aneurysms in diabetics. Brit. J. Ophthal. $34,495-505(1950)$.

14. Scarpelli, P.T., and R. Brancato: Studio bioptico dei microvasi congiuntivali nel diabete mellito: nuovi aspetti istopatologici. Ann. Ottal, 91, 1673-1688 (1965).

Dr. M. C. BaLodimos

170 Pilgrim Road

Boston, Massachusetts USA 